\title{
CONSUMERS' PREFERENCES FOR LOCALLY PRODUCED HONEY IN HUNGARY
}

\author{
Titanilla Oravecz ${ }^{1}$, Laszlo Mucha², Robert Magda³ ${ }^{3}$ Gedeon Totth ${ }^{1}$, \\ Csaba Bálint Illés ${ }^{4}$
}

\footnotetext{
${ }^{1}$ Marketing Department, Faculty of International Management and Business, Budapest Business School, H-1165, Budapest, Diósy Lajos u. 22-24., Hungary

${ }^{2}$ Doctoral School of Management and Business, Szent István University, H-2100, Gödöllő, Páter Károly utca 1., Hungary

${ }^{3}$ Department of Microeconomics, Faculty of Economics and Social Sciences, Szent István University, H-2100, Gödöllő, Páter Károly utca 1., Hungary

${ }^{4}$ Institute of Business Economics, Leadership and Management, Faculty of Economics and Social Sciences, Szent István University, H-2100, Gödöllő, Páter Károly utca 1., Hungary
}

Link to this article: https://doi.org/10.11118/actaun202068020407

Received: 16. 2. 2020, Accepted: 10. 3. 2020

To cite this article: ORAVECZ TITANILLA, MUCHA LASZLO, MAGDA ROBERT, TOTTH GEDEON, ILLÉS CSABA BÁLINT. 2020. Consumers' Preferences for Locally Produced Honey in Hungary. Acta Universitatis Agriculturae et Silviculturae Mendelianae Brunensis, 68(2): 407-418.

\begin{abstract}
Sustainability is considered in relation to the consumption of local food. Consumers have recently become more concerned about food safety, including potential impurities in Asian honey. Some consumers believe that eating local honey products might be a way to avoid food safety risks. Food security is also guaranteed by certification marks that create confidence in consumers, and help their decisions in buying.

The aim of the paper is to identify the main characteristics of Hungarian consumer preferences when buying honey. In this article we analyse the consumer behaviour of Hungarian hive products. This study was supported by the data from a nationwide consumer survey carried out in 2016. A total of 1584 subjects participated in this survey, the sample is representative for gender, age and highest level of education in Hungary. The results of our study show the actual potential consumers of the Hungarian honey products. Based on the results, the consumers we interviewed consider the consumption of honey of Hungarian origin very important, and they prefer to purchase these products directly or indirectly from the beekeepers. Well-informed consumers in terms of honey certification marks consider some features of honey (Hungarian origin; region of origin; brand, producer name; certification marks) significantly more important than uninformed consumers. Awareness of the certification marks helps consumer decisions which are confirmed by the fact that consumers who are informed about honey certification marks were not affected by honey counterfeits.
\end{abstract}

Keywords: consumer, consumer behaviour, certification marks, honey consumption, local food, retail, sustainability

\section{INTRODUCTION}

\section{Sustainable Consumption}

According to Reisch and Ropke (2004) recently, consumption has become the focus of attention within sustainable development. Sustainable consumption can be interpreted as the usage of products to provide basic needs and minimize the release of toxic and hazardous substances, waste and pollutants (Nádudvari, 2004). Sustainable consumption is a widely understood and controversial concept of social and environmental aspects such as 
environmental protection, human rights, and intergenerational equity (Pepper et al., 2009). The growing rate of diseases resulting from the unhealthy lifestyle of consumers has contributed to the popularity of sustainability (Szakály, 2011). The consumption of organic farming products become a trend on the food market (Predanocyová et al., 2018).

\section{Economic-social Factors Determining Food Consumption}

Food consumption can be affected by many factors and apart from one's own personal biological preferences it is influenced directly by demographic, economic, sociological, psychological, antrophological and political factors (Lehota, 2004). Furthermore, gender, age and work are main factors that are helpful to show differences in food consumption as shown by several studies (Hulshof et al., 1991; Smith and Baghurst, 1992; Roos et al., 1996; Johansson et al., 1999; Irala-Estevez et al., 2000; Dowler, 2001; Roos et al., 2001). These main factors were identified and complemented with individual lifestyle, ethnicity, education and place of residence by Hayn et al. (2005). Lehota (2004) identifies income as one the most determining factors within the socio-economic macro enviroment. An international research carried out in welfare societies (Belgium, Denmark, Estonia, Finland, Germany, Lithuania, Norway, Spain, Sweden and the UK) shows a positive correlation between fruit and vegetable consumption and education (Irala-Estevez et al., 2000).

\section{The Environmental Impact of Food Consumption}

Amongst of other factors regarding the direct and indirect consumption of households Lorek (2005) found that food consumption has the greatest impact environmentally. Other studies suggest that with the general growth of population it is expected to increase (McMichael et al., 2007; Myers et al., 2004; Tilman, 1999). Food consumption, as one of the most polluting activities (Carlsson-Kanyama et al., 2003) accounts typically 20-30\% of the the environmental impact of a household, which includes a particularly significant part of dairy and meat consumption (Tukker et al., 2006; Carlsson-Kanyama and González, 2009; Druckman et al., 2011). This ratio increases to $70 \%$ if the energy usage is included in the full life cycle analzsis (Tukker et al., 2006; Tukker and Jansen, 2006). To the overall impact agricultural production makes the largest contribution, for nearly half of food-related GHG emissions it could be accounted in developed and less developed regions as well. Although, regardless the size of the post-supply harvest chain, not every food product contributes equally to the relevant environmental impacts, such as pollution, biodiversity loss or resourse depletion. As mentioned before, not only that meat and dairy production adds a lot to the households' environmental impact, they also responsible for the majority of the environmental burden, especially when it concerns the GHG emission (Williams et al., 2006; EC, 2006; Leip et al., 2010); Westhoek et al., 2011). Smil (2000) found that food provision itself has the greatest impact environmentally amongs human activity. Over-consumption can not only lead to under-consumption in other areas regionally or of others (Princen, 1999), but also it may lead to negative effects regarding the environment, health or social areas.

\section{Sustainable Food Consumption}

The idea of the sustainability of food consumption includes the most effective usage of resources and maintaining their availibilty whilst minimising the negative effects and thus producing enough food to maintain the human population. This or similar definitions of sustaiinable consumption could be viewed as inappropriate (Kiss, 2011) because it simply cannot be sustainable in most parts of the world, not even in currently developing countries. The food supply requires great proportion of surface water as well as energy and considering the current chain it could be improved stepwise rather than by adjunctions.

Stepwise improvements can include many alternatives which are studied. Vermeir and Verbeke (2004) suggests organic farming offers ethical products which can be traded fairly and are animal friendly in production of dairy and meat. Duchin (2005) recommends a so called sustainable diet, which has a relatively low environmental impact compared to the average food consumption conduct and also provides the essential needs for a healthy life. Pack et al. (2005) finds that this consumption includes a preference for local products to ones that have been imported and therefore have not met a low energy intensity due to the extensive supply chain. Alferdsson (2002) introduces the term green diet (green consumption), which includes such products and consumer patterns that has low energy intensity and $\mathrm{CO}_{2}$ emission. This is compatible with the study of Hayn, Empacher and Halbes (2005), which reports that a sustainable diet combines the healthy eating habits and the implement of positive health and the environment.

Considering the above definitions and approaches, Leiztmann (2003) points out seven attributes for food that are compatible with sustainable food consumption. The food should be mostly plant based, seasonal, produced in an organic farm, which is local, has a low degree of processing, is marketed and fair trade.

The true underlying challenge of a sustainable food consumption is growth of mankind and needs. Despite all difficulty, Smil (2000) sees no fundamental biophysical obstacles to feeding ten billion people by 2050. Responsible and reasonable 
use of current resources and the technological improvements can help to build a food supply chain that is sustainable and has less negative impacts on the environment.

\section{Relationship between Local Food Consumption and Sustainability}

Throughout history, it was an easy and logical way to sell and market products close to their place of production, such as farmers' markets, roadside or direct sales have been proven effective for agricultural products. As mankind evolved the distributional opportunities increased. There is not one single and well approved definition of the term 'local' in regard to food, it could be summerised in a way where the process of production and distribution in a certain distance, which excludes national or international trading. According to Heron and Oglethorpe (2009) there are many interpretations of it when it comes to individual retailers.

Through the scientific literature the same rules apply, even though there are personal relations between the separate stages of the food supply chain and regional limits (Schönhart et al., 2008; Allen, 2010). Considering the distance, the National Association of Farmers' Markets (NAFM) in the United Kingdom recommends that a 30 mile radius from the market is ideal and within 50 miles it is satisfactory (Jones et al., 2004). Furthermore, there is a difference between local food - one which has been produced and consumed locally - and locality food (produced locally and consumed globally (Brunori, 2007). Food miles take their own proportion of the negative impact of consumption and there's a tendency to believe that local food could offer a solution to decrease the effects in a direct way (Coley et al., 2008) linked it to carbon accounting). Compared to the global food chains with high energy consumption, local food systems are seen as a less polluting alternative (NorbergHodge, 2002). As the supply chain has grown to a global extent, it brought the same queries that can be more difficult to look into - real origin, quality, health value, the ethicality and sustainability of production. Considering the size and participants of a local food supply chain is is often considered to be more sustainable compared to a global food supply chain (see SUSTAIN, 2009; Smith, 2008). According to Ilbery and Maye (2005) product labelling or imagery help consumers to get information about the production process and the area of origin.

Deloitte (2007) points out that compared to other industries, food production is less global. Short supply chains and local trading have other benefits as well. According to Dunay et al. (2018) those farmers, who have a preference to local marketing and shorter supply chains, achieved other values with their production, such as being environmant friendly and preserving local values. Ilbery and
Maye (2005) show compatible findings, it is assumed in the study that local food supply chains are more sustainable along other benefits, such as saving energy, reducing food miles, practising social care through a personal relationship and having an economic value in their local economic system.

Local food initiatives have the opportunity to broaden their potentials, but they have to and need to be closely connected to the politics of alternative food systems. Local food initiatives profit from certain relations to their value-based commitments, their connection to social economy and sustainable community development (Guthman, 2008).

\section{Honey}

Honeybee colonies ensure plant reproduction by pollination that is why they are essential for agriculture and environment. Beekeeping has a major importance in the development of rural areas. A recent research of Šedík et al. (2019) showed that honey is considered and consumed as food product and medicine as well, and the majority of consumers think honey has healing effects.

As the world's second most important honey producer after China (543,000 tonnes, 29\% of total honey production), the European Union (230,000 tonnes, $12 \%$ of total honey production) offers a variety of apiculture products not just honey, but also pollen, propolis, royal jelly and beeswax (FAOSTAT, 2018). Global sales from natural honey exports by country totaled US $\$ 2.2$ billion in 2018. According to FAOSTAT (2018) and ITC (2019), China (US\$249.3 million, 11.2\%) has the highest share of natural honey export in the world. New Zealand with $\$ 245.2$ million (11\%) is the second one, and Argentina with $\$ 175$ million (7.8\%) is the third. Hungary has the $10^{\text {th }}$ highest share of natural honey export in the world. According to Pocol et al. (2017) Italy is a net importer, while Serbia and Romania - with a positive trade balance - are net exporters. According to FAOSTAT (2018) and ITC (2019) United States spent the most on imported natural honey during 2018 (US\$504.2 million, $22.5 \%$ ). Germany with $\$ 305.7$ million (13.6\%) is the second one, and Japan with \$145.4 million (6.5\%) is the third. European countries bought the highest dollar worth of imported natural honey during 2018. This continent purchased $\$ 1.2$ billion or $52.3 \%$ of the global total, European countries are the largest global consumers of honey with $20 \%$ of the total global consumption. North American countries with $23.8 \%$ are the second one. From a continental perspective Asia purchased the $20 \%$ of worldwide natural honey.

According to Šedík et al. (2017) since 2007, Slovakia and Romania have an increasing trend in number of hives. The Slovakian production of honey is stable, while the Romanian production has been continuously increasing since 2007. The European Union is a net importer of honey, because the 
production within the European Union accounting for only $60 \%$ of EU citizens' consumption. The European Union is the second largest producer of honey in the world, but its production seems to be declining. The No. 485/2013 regulation of the European Union aims using pesticides that are attractive to bees and pollinators. This regulation may have a positive effect on bee health and bee populations in Europe.

\section{Local Honey Consumption}

Local honey is more beneficial to consumers than imported honey, Allsopp et al. (2008), highlighted that the most important consequence is the positive environmental externalities. For maintaining the local ecological balance the pollination by local bee colonies is essential. Morse and Calderone (2000) and Gallai et al. (2009) found that pollination plays a role in $10 \%$ of the food consumed by humanity. According to Häagen-Dazs (2013) and Rajan et al. (2002) the consumption of local honey can - according to many consumers - help to cure allergies.

Šedík et al. (2018b) study evaluated chemical, biological, microbiological and antibacterial properties of twenty different polyfloral honey samples. The first ten were commercial honeys from a selected supermarket with country of origin indicated as "blend of EU and non-EU honeys" while second ten were honeys from local beekeepers representing the domestic origin. Local honeys obtained better results in antioxidant activity, antimicrobial activity and possess no detectable microorganisms. Heavy metals (cadmium, lead and chrome) were not detected in either of the samples. Melnick (2011) and Schneider (2011) explain that consumers have recently become more concerned about food safety and more aware of worldwide food safety issues, including potential impurities in Asian honey. Some consumers believe that eating local honey products might be a way to avoid these food safety risks, which plays an important role in international honey trade (Popp et al., 2018). Bittsánszky et al. (2018) highlighted that the main responsibility for food safety shall be taken by the food producers and food providers.

Food security is also guaranteed by trademarks that create confidence in consumers, and help their decisions in buying. Many trademarks can be used on food in Hungary, for honey the Hungarian Honey seal, locking tape, stamp holograms, and Producer Honey Jar issued by the Hungarian Beekeepers Association, Hungarian Product, Honey of the Year, Excellent Hungarian Honey of the Year, Product Trademarks of the National Park, Traditions-Flavors-Regions, Excellent Hungarian Food and various local brand brands.

According to statutory requirements labels on food packaging are basically divided into two groups: 1) mandatory labels as defined by the Regulations, such as the name of the food, its net quantity, date of consumption, name and address of the distributor or, in certain cases, origin or place of origin and 2) other elements not required by law. These (2) may include nutrition claims, functional claims and trademarks, certification marks, and geographical indications (Dörnyei, 2011; Rácz, 2013). The use of food labels is widely regulated by laws, regulations and EU directives. Currently, the use of non-mandatory elements are supervised by state-owned or non-profit companies, such as Hungarian Product Nonprofit Ltd., Agricultural Marketing Centre, and National Hungarian Beekeeping Association).

In 2019, 3 producers of honey have the Traditions-Flavors-Regions certification mark for 8 products, 4 producers of honey have the Excellent Hungarian Food certification mark for 9 products, and the Hungarian Product certification mark is used by 6 honey producers, and 6 honey distributors. During our research, we dealt with the three most significant certification marks, namely the Hungarian Honey Seal and the Producer Honey Bottle and the Hungarian Product Trademark in numerous honey varieties.

In 2018, almost 4,000 products of more than 170 companies had the Hungarian Product certification mark, helping to identify the domestic products easily and clearly, increasing the demand for Hungarian products. An independent expert check assay in the Hungarian Product Trademark System proves the origin and reliability of the product. The certification mark guarantees to consumers that the given food is made from 100\% Hungarian raw material, and is produced in Hungary (Hungarian Product, 2019).

In the case of honey, this means that the bees have been raised in Hungary, the nectar plant has been cultivated in Hungary and every step of the processing has taken in Hungary. The Hungarian Honey Seal and Producer Honey Jar provides a guarantee for consumers that they find a 100\% nectar, natural and Hungarian honey in the bottle. The Hungarian Beekeepers Association's trademarks can only be used by authorized Hungarian honey producers with valid membership. The ingredients of the products of the beekeepers using the Sealing Tape and the Honey Jar is analyzed by the Hungarian Beekeepers Association by random sampling in an accredited laboratory, guaranteeing the natural, Hungarian origin and excellent quality of the branded honey (Hungarian Beekeepers Association, 2010, 2012).

\section{MATERIALS AND METHODS}

The results of our research introduce the consumer perception of the typical certification marks for honey, with special regard to the Hungarian Product Trademark and the Hungarian Honey Tape and Honey Jar issued by the Hungarian Beekeepers Association. The aim of the paper is 
to identify the main characteristics of Hungarian consumer preferences when buying honey. The goal of the 2016 consumer survey was to explore the main features of consumer behavior related to honey and the consumer knowledge and expectations about the quality of honey. An important part of the research was the awareness of the food certification marks and their impact on consumer behavior, for which no similar research has been yet made in Hungary, so it can be said to be new based on the results.

The honey consumer research was conducted for the Central-Hungary (Budapest and Pest County) statistical region (HCSO, 2016), primarily for convenience reasons, as it was personally interviewed for all questionnaires. Of the various sampling techniques, random sampling techniques were used, so anyone could get into the sample. The sample was selected using the following filtering condition: only persons over the age of 18 were allowed to participate in the study that consume honey at least every six months and participate in the selection process when buying honey. According to the 2016 national microcensus data (HCSO, 2017) the research $(n=1584)$ is representative for gender (observed prop. $=0.4747$; test prop. $=0.4693 ; \mathrm{p}=0.341$ ), age $\left[X^{2}(d f=5, N=1524)=0.027 ; p=1.000\right]$ and highest level of education $\left[\chi^{2}(\mathrm{df}=4, \quad \mathrm{~N}=1524)=0.070\right.$; $\mathrm{p}=0.999]$ in Hungary. From socio demographic point of view, the sample comprises both males $(47.5 \%)$ and females (52.5\%) in age of 18-24 years (9.9\%), 25-34 years (15.2\%), 35-49 years (28.3\%), 50-59 years (15.1\%), 60-74 years $(22.0 \%)$, over 75 years (9.5\%), with elementary education (23.9\%), secondary vocational education (21.8\%), secondary education (33.2\%) and higher education (21.1\%).

The primary research was conducted in a personal interview by a paper-based questionnaire. The questionnaire is the most frequently used research tool for collecting primary data (Kotler and Keller, 2012). Compiling the terms of content and the form of questionnaire used during the survey, we tried to clarify, and sort the questions, and eliminate any ambiguity. We used both open and decisive questions in the questionnaire and the respondents had to evaluate certain findings on a scale of 1 to 5 . Frequency analyzes and cross-table analyzes were performed to analyze the questionnaire responses, in the case of the background variables we analyzed only the more significant, significant differences. The cross-table analysis as a method highlights the relationships between variables (Sajtos and Mitev, 2007). The statistical significance of the relationship between the variables was measured by Chi-square statistics and Cramer's V coefficients (Malhotra, 2005). We used MS Excel and SPSS 25.0 for the evaluation. Frequency analysis and crosstable analysis were used to analyze questionnaire responses. The personal data of the interviewees enjoyed full protection and anonymity.

\section{RESULTS AND DISCUSSION}

According to Rácz (2013), the role of information in the pre-purchase phase of the purchasing decision process is very important for conscious consumer groups. Consumers expect credible and extensive information about the food they buy. The various of certification marks provide a guarantee for consumers that these products have the best product features. The most respondents of our research knew the Hungarian Product certification mark (50.8\%), while the average notoriety of the Honey Jar was 38.1\%, while the notoriety of Sealing Tape in the whole sample was $37.4 \% .16 .2 \%$ of the respondents were familiar with all 3 certification marks, we identified them as informed consumers (in terms of trademarks). During the analysis, we would like to present the differences and relationships between well-informed consumers in terms of honey certification marks (256 people) and uninformed consumers in terms of honey certification marks (1328 people).

Significant correlation $(p<0.05)$ was found between well-informed/uninformed respondents and the gender $\left[\left(\chi^{2}=11248 ; d f=1 ; p<0.001\right)\right.$; (Cramer's V $=0.084 ; p=0.001)$ ], and the highest level of education [ $\left(\chi^{2}=13925 ; \mathrm{df}=4 ; \mathrm{p}=0.008\right)$; (Cramer's $\mathrm{V}=0.094 ; \mathrm{p}=0.008)]$. In terms of age, the older age group was dominant. Well-informed consumers typically have over 50 years of age (49.6\%), with at least a high-school graduation (61.7\%), with a higher than average (51.2\%) income, they are Budapest (47.7\%) and urban (32.4\%) residents, mostly women (62.1\%).

Based on the research of Árváné (2011), we assumed that the origin of the honey (which can be considered a product of trust because of fake honey) is very important, that is why the main sources of buying are beekeepers and producer markets. According to Šedík et al. (2018a) the most frequent place of purchase in Slovakia is directly from the beekeeper and farmers' markets. The respondents between 25-40 years would prefer to buy honey from pharmacies or vending machine. Guziy et al. (2017) found that young generation tends to consume less honey per year than older generation, therefore they suggested educating the young generation tends to consume less honey per year than older generation.

The respondents of our research typically buy honey from the beekeeper (70.81\%), in the shop (43.9\%) or at the market (39.7\%). The proportion of direct sales is almost double than the proportion of indirect sales in both well-informed and uninformed consumers. Compared to the average of all respondents, well-informed consumers in terms of trademarks buy more personally from the beekeepers. $75.0 \%$ of them choose producers as a source of honey purchasing, $48.0 \%$ of them buy honey in the market, and 39.1\% of them buy in a shop. The proportion of online purchases is 


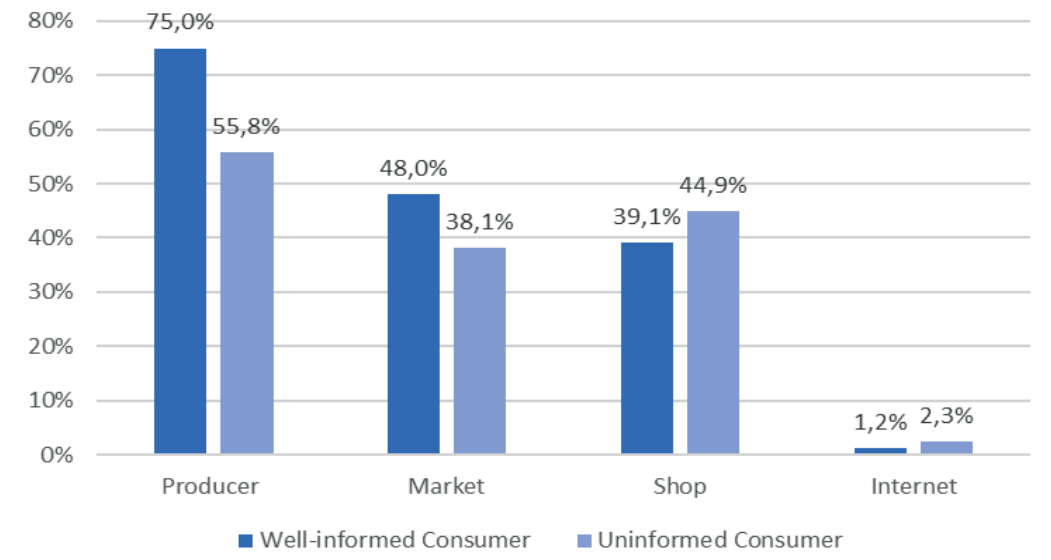

1: The most common places to buy honey Source: Own research, 2016, $n=1584$

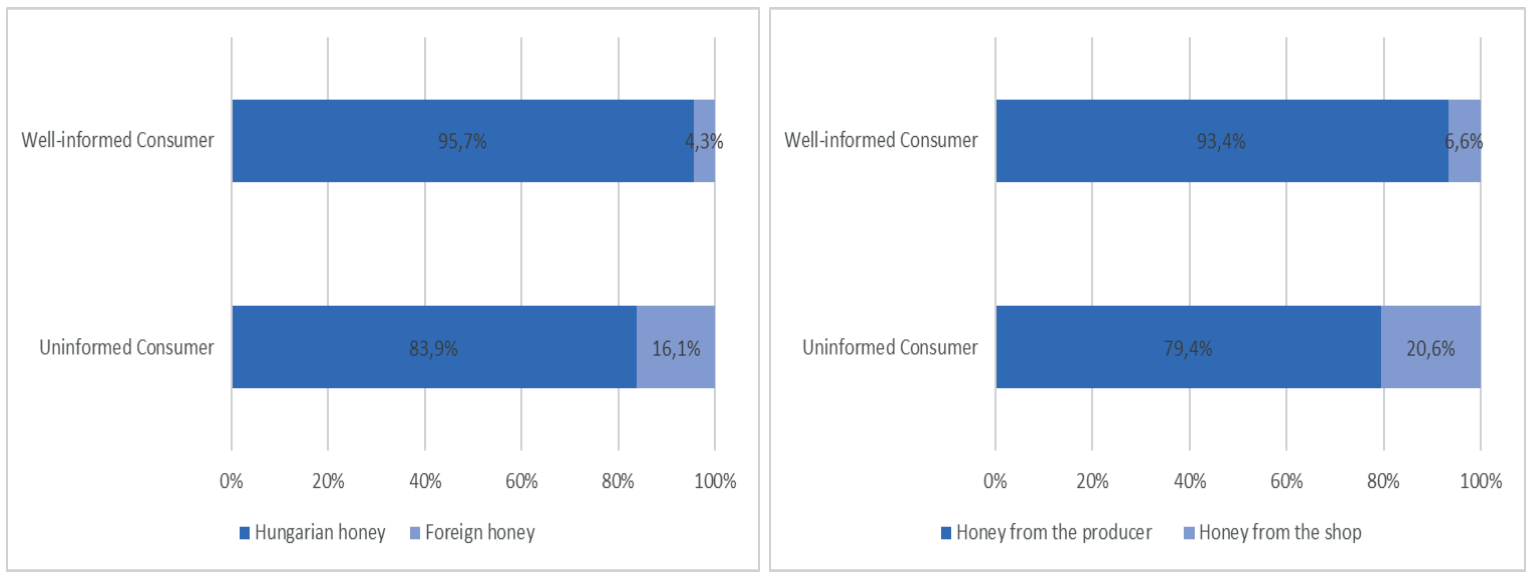

2: Honey preferences (domestic or import and honey from the beekeepers or from the shop) Source: Own research, 2016, $\mathrm{n}=1584$

extremely low for both well-informed (1.2\%) and uninformed consumers (2.3\%). Fig. 1 shows the typical locations of honey purchase. Examining the relationship between the sources of purchase of honey and the demographic variables of the wellinformed consumers (in terms of trademarks), no significant correlation ( $p>0.05$ ) was found between the place of purchase and age, income and the type of residence of the respondents. Significant correlation $(p<0.05)$ was also found between the income and the purchasing on the market (Cramer's $V=0.210 ; p=0.024$ ), costumers with higher income prefer to buy honey in the market.

In their study Szakály and Szabó (2009) analyzed the importance of direct sales in everyday shopping. According to their survey, if consumers want to buy Hungarian food, then the importance of the shops is significantly lower than the proportion of indirect or direct purchases from the producers or from the markets. When buying Hungarian food, Hungarian consumers prefer different forms of direct sales because of the personal atmosphere of producer markets which can creates confidence in consumers. Their result is supported by our research; our respondents clearly prefer direct and indirect purchases from the producer when they buy honey.

When our respondents had to decide whether to choose Hungarian or foreign honey, and from Hungarian producers, or from the shop, both groups clearly preferred domestic and producer's honey. All respondents prefer Hungarian (85.8\%) honey to foreign honey (14.2\%), and honey from producers $(81.7 \%)$ to honey $(18.3 \%)$ from stores. Our study revealed the relationship between wellinformed consumers and the purchasing of honey from Hungarian producers $\left[\left(\chi^{2}=27792 ; d f=1\right.\right.$; $\mathrm{p}<0.001) ; \quad$ (Cramer's $\mathrm{V}=0.132 ; \mathrm{p}<0.001)$ ] and Hungarian origin $\left[\left(\chi^{2}=24595 ; \mathrm{df}=1 ; \mathrm{p}<0.001\right)\right.$; (Cramer's $V=0.125 ; \mathrm{p}<0.001)$ ]. Well-informed consumers choose Hungarian honey (95.7\%) instead of foreign honey, and from Hungarian producers (93.4\%), then from the shop. Although members of the uninformed group also prefer these answers, their values (83.9\%; 79.5\%) are below the values of the well-informed group (Fig. 2).

Based on Predanocyová et al. (2018) results, on organic food market for the customers the quality 


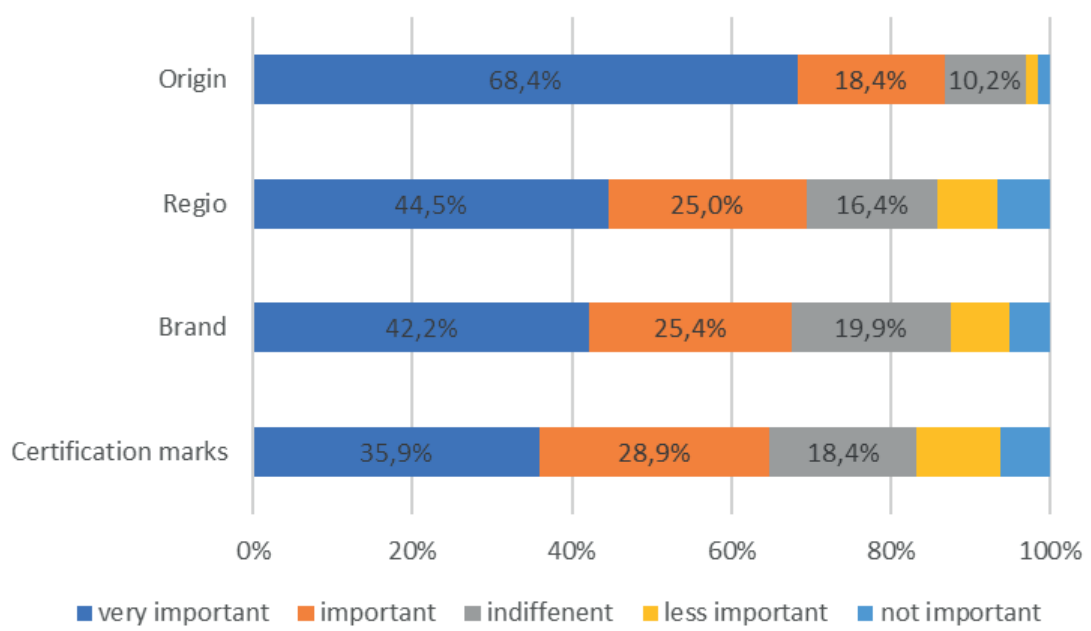

3: Ranking of product qualities determining the purchase of honey in the well-informed costumer (in terms of certification marks) group

Source: Own research, 2016, $n=256$

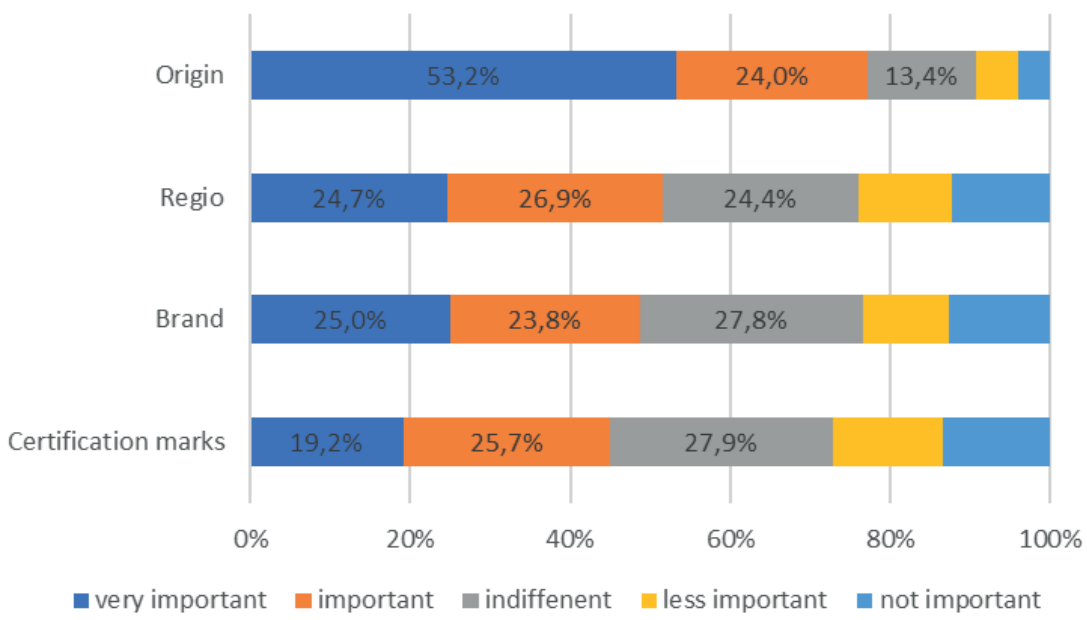

4: Ranking of product qualities determining the purchase of honey in the uninformed costumer (in terms of certification marks) group

Source: Own research, 2016, $n=1328$

and the origin of the food play an important role. In case of honey purchase among the Slovak consumers, according to Guziy et al. (2017) the country of origin were very important, while the Russian consumers find other product features more important than the country of origin.

According to our respondents when they buy honey, Hungarian origin is a very important feature, while the region of origin, the brand, the producer name and the certification mark are important attributes (Fig. 3 and 4). Well-informed respondents consider these features of honey significantly more important - Hungarian origin: $\left[\left(\chi^{2}=34601 ; d f=4 ; p<0.001\right) ;(C r a m e r ' s \mathrm{~V}=0.148\right.$; $p<0.001)]$ region of origin $\left[\left(\chi^{2}=46121 ; d f=4\right.\right.$; $\mathrm{p}<0.001$ ); (Cramer's $\mathrm{V}=0.171 ; \mathrm{p}<0.001$ )] brand, producer name $\left[\left(\chi^{2}=63293 ; \quad d f=4 ; \quad p<0.001\right)\right.$; (Cramer's V $=0.200 ; p<0.001)$ ] certification marks $\left[\left(\chi^{2}=74751 ; \mathrm{df}=4 ; \mathrm{p}<0.001\right)\right.$; (Cramer's $\mathrm{V}=0.217$; $\mathrm{p}$ <0.001)] - than uninformed consumers. $68.4 \%$ of well-informed consumers consider the origin of the honey very important, compared to $53.2 \%$ of uninformed consumers. $69.5 \%$ of well-informed consumers consider the origin of honey to be very important or important for the region, compared to $51.6 \%$ for uninformed consumers. In the case of honey, the brand is synonymous with the producer's name, and $42.2 \%$ of well-informed consumers consider this attribute very important when they buy. Certification marks on the packaging is a very important attribute of honey for $64.8 \%$ of wellinformed consumers. This product feature is also important for uninformed consumers, as almost half of the group (44.9\%) consider it very important or important when shopping honey.

We asked the participants of our research about the influence of honey counterfeits on their buying habits. $41.1 \%$ of the respondents buy honey only 


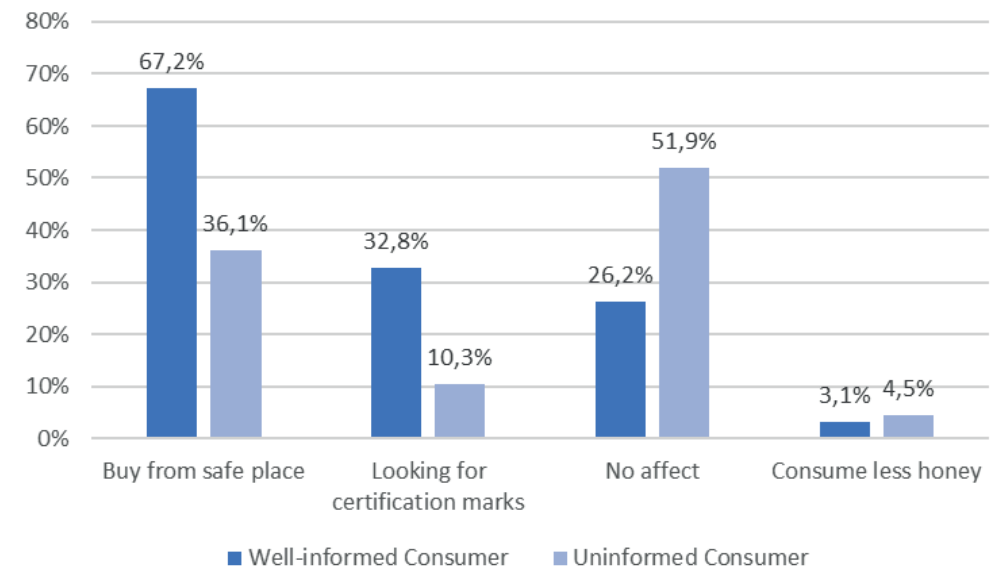

5: Effects of honey scandals on consumers

Source: Own research, 2016, $n=1584$

from a safe place, $14.0 \%$ of them looks for signs of quality assurance, and $4.3 \%$ use less honey as a result of honey scandals in recent years. Fig. 5 illustrates the effects of honey scandals on consumers. The quarter of consumers $(26.2 \%)$ who are well-informed about certification marks were not affected by honey counterfeits, unlike the value (51.9\%) of uninformed costumers. Well-informed consumers typically buy honey from a safe place (67.2\%), uninformed consumers (36.1\%), significant correlation with a weak relationship between the variables was found $\left[\left(\chi^{2}=85854 ; \mathrm{df}=1 ; \mathrm{p}<0,001\right)\right.$; (Cramer's $V=0,233 ; p<0,001)$ ]. Fig. 5 illustrates that well-informed consumers consider greater importance to honey counterfeiting scandals than uninformed consumers and have a more sophisticated defense strategy to avoid buying fake honey. Almost three times higher part of well-informed consumers (32.8\%) are looking for certification marks to avoid buying counterfeit honey than uninformed respondents (10.3\%).

\section{CONCLUSION}

According to our research, the respondents consider Hungarian honey is higher quality than foreign product, they prefer buying honey from producers to purchasing honey from shops, and they consider producers' honey is higher quality than products from shops. The interviewees consider the origin and the quality as the most important product characteristics determining the purchase of honey, because being a trust product, honey is preferred to purchase from beekeepers, and producer markets.

The increase of the consumer awareness increases the importance of information that help consumers make decisions. The level of the consumer awareness is variable, but the most informed consumers are mostly metropolitan and urban residents at least 50 years of age with at least a high school diploma, and a high salary. Honey is a trust product, which is confirmed by the fact that the source and the quality are the most important factors that influence the purchase of honey. It can also be concluded that the proportion of direct sales of buying honey is very high without reference to the level of consumer awareness, and significantly high in the informed consumers group. This is very much in line with the general tendency of that direct sales is the most preferred way to purchase domestic products. In the case of purchasing honey, Hungarian origin and beekeepers' honey were particularly preferred. Because of the recent scandals of honey counterfeiting, two-thirds of the respondents buy honey only from a safe place, and nearly a third of them looks for signs of quality assurance. Only a few of the respondents reduced their honey consumption as a result of scandals. Awareness of the certification marks helps consumer decisions which is confirmed by the fact that consumers who are informed about trademarks were not affected by honey counterfeits. The results of the research can help the work of the beekeepers, they can find the right tools of communication with consumers, which increases their competitiveness.

Acknowledgements

Supported by the ÚNKP-19-3-III-SZIE-6 New National Excellence Program of the Ministry for Innovation and Technology. 


\section{REFERENCES}

ALFREDSSON, E. C. 2002. “Green” Consumption- no solution for climate change. Energy, 29(4): 513-524.

ALLEN, P. 2010. Realizing justice in local food systems. Cambridge Journal of Regions, Economy and Society, 3(2): 295-308.

ALLSOPP, M. H., DE LANGE, W. J. and VELDTMAN, R. 2008. Valuing Insect Pollination Services with Cost of Replacement. PLOS ONE, 3(9): e3128.

ÁRVÁNÉ, V. G. 2011. Marketing analysis of the honey market with special regard to consumer and consumer behavior [in Hungarian: A mézpiac marketing szempontú elemzése különös tekintettel a fogyasztói és vásárlói magatartásra]. PhD. Thesis. University of Debrecen, Karoly Ihrig Doctoral School of Management and Business.

BITTSÁNSZKY, A., DUNAY, A., TÓTH, A. J. and SERREM, K. 2018. Evaluation of professional knowledge of cooks and storage managers in secondary schools. In: BYLOK, F., ALBRYCHIEWICZ-SŁOCIŃSKA, A. and CICHOBLAZINSKI, L. (Eds.). $8^{\text {th }}$ International Conference on Management: Leadership, Innovativeness and Entrepreneurship in a Sustainable Economy. Czestochowa: Wydawnictwo Wydzialu Zarzadzania Politechniki Czestochowskiej, pp. 65-69.

BRUNORI, G. 2007. Local food and alternative food networks: a communication perspective. Anthropology of Food, S2: 430.

CARLSSON-KANYAMA, A., EKSTRÖM, M. P. and SHANAHAN, H. 2003. Food and life cycle energy inputs: consequences of diet and ways to increase efficiency. Ecological Economics, 44(3): 293-307.

COLEY, D., HOWARD, M. and WINTER, M. 2008. Local food, food miles and carbon emissions: a comparison of farm shop and mass distribution approaches. Food Policy, 34(2): 150-155.

DELOITTE. 2007. An appetite for change. Food and Beverage 2012. Deloitte. [Online]. Available at: www.deloitte.com/dtt/cda/doc/content/An\%20appetite\%20for\%20change.pdf [Accessed: 2008, February 19].

DOWLER, E. 2001. Inequalities in diet and physical activity in Europe. Public Health Nutrition, 4(2): 701-709.

DÖRNYEI, K. 2011. Investigating consumer information search behavior on food packaging [in Hungarian: Fogyasztói információkeresési magatartás vizsgálata élelmiszerek csomagolásán]. PhD. Thesis. Corvinus University of Budapest, Doctoral School of Business.

DUCHIN, F. 2005. A Framework for Analyzing Scenarios about Changes in Diets. Journal of Industrial Ecology, 9(1-2): 99-114.

DUNAY, A., LEHOTA, J., MÁCSAI, É. and ILLÉS, B. C. 2018. Short Supply Chain: Goals, Objectives and Attitudes of Producers. Acta Polytechnica Hungarica, 15(6): 199-217.

EUROPEAN COMMISSION. 2006. Environmental impact of products (EIPRO): analysis of the life cycle environmental impacts related to the total final consumption of the EU25. European Commission Technical Report EUR 22284 EN. Brussels: European Commission. Available at: http://ipts.jrc. ec.europa.eu/publications/pub.cfm?id=1429 [Accessed: 2019, August 20].

EUROPEAN UNION. 2013. Ommission Implementing Regulation (Eu) No. 485/2013 of 24 May 2013, amending Implementing Regulation (EU) No. 540/2011, as regards the conditions of approval of the active substances clothianidin, thiamethoxam and imidacloprid, and prohibiting the use and sale of seeds treated with plant protection products containing those active substances. Brussels: European Union. Available at: https://eur-lex.europa.eu/LexUriServ/LexUriServ.do?uri=OJ:L:2013:139:0012:0 026:EN:PDF [Accessed: 2019, May 19].

FOOD AND AGRICULTURE ORGANIZATION OF THE UNITED NATIONS: FAOSTAT. 2019. FAOSTAT. [Online]. Available at: http://www.fao.org/faostat/en/\#home [Accessed: 2019, May 04].

GALLAI, N., SALLES, J. M., SETTELE, J. and VAISSIERE, B. E. 2009. Economic valuation of the vulnerability of world agriculture confronted with pollinator decline. Ecological Economics, 68(3): 810-821.

GUTHMAN, J. 2008. Neoliberalism and the Making of Food Politics in California. Geoforum, 39(3): 1171-1183.

GUZIY, S., ŠEDÍK, P. and HORSKÁ, E. 2017. Comparative study of honey consumption in Slovakia and Russia. Potravinárstvo / Slovak Journal of Food Sciences, 11(1): 472-479.

HÄAGEN-DAZS. 2013. Häagen - Dazs - Help the Honey Bees. [Online]. Wilkes-Barre, PA: HäagenDazs. Available at: http://www.helpthehoneybees.com [Accessed: 2013, February 21].

HAYN, D., EMPACHER, C. and HALBES, S. 2005. Trend und Entwicklung von Ernährung im Alltag: Ergebnisse einer Literaturrecherche. Frankfurt am Main: Institut für sozialökologische Forschung (ISOE).

HERON, G. and OGLETHORPE, D. 2009. A road to nowhere? Logistics and distribution barriers faced by local food supply chains. In: Proceedings of the $14^{\text {th }}$ Annual Logistics Research Network Conference. September 9-11, 2009. Cardiff, UK, pp. 29-37. 
HULSHOF, K. F., LOWIK, M. R. and KOK, F. J. 1991. Diet and other lifestyle factors in high and low socioeconomic groups (Dutch Nutrition Surveillance System). European Journal of Clinical Nutrition, 45: 441-450.

HUNGARIAN BEEKEEPERS ASSOCIATION. 2010. Hungarian honey. "Quality, Value, Tradition" [in Hungarian: Magyar méz. "Minőség, érték, tradíció”]. Budapest: Hungarian Beekeepers Association.

HUNGARIAN BEEKEEPERS ASSOCIATION. 2012. Hungarian producer honey directly from the beekeeper [in Hungarian: Magyar termelői méz közvetlen a méhésztőll. Budapest: Hungarian Beekeepers Association.

HUNGARIAN BEEKEEPERS ASSOCIATION. 2019. Hungarian Beekeepers Association. [Online]. Available at: https://omme.hu/ [Accessed: 2019, May 16].

HUNGARIAN CENTRAL STATISTICAL OFFICE: HCSO. 2016. Large statistical regions [in Hungarian: Statisztikai nagyrégiók]. [Online]. Available at: http://www.ksh.hu/teruleti_atlasz_megyek [Accessed: 2016, August 17].

HUNGARIAN CENTRAL STATISTICAL OFFICE: HCSO. 2017. Mikrocenzus 2016: Population Enumeration. [Online]. Available at: http://www.ksh.hu/mikrocenzus2016/ [Accessed: 2017, December, 01].

HUNGARIAN PRODUCT. 2019. Hungarian Product [in Hungarian: Magyar Termék]. [Online]. Available at: https://amagyartermek.hu/ [Accessed: 2019, May 16].

ILBERY, B. and MAYE, D. 2005. Food supply chains and sustainability: evidence from specialist food producers in the Scottish/English borders. Land Use Policy, 22(4): 331-344.

IRALA-ESTEVEZ, D. J., GROTH, M., JOHANSSON, L. and OLTERSDORF, U. 2000. Systematic review of socio-economic differences in food habits in Europe: consumption of fruits and vegetables. European Journal of Clinical Nutrition, 54(9): 706-714.

ITC. 2019. Trademap. [Online]. Available at: https://www.trademap.org/Index.aspx [Accessed: 2019, May 04].

JOHANSSON, L., THELlE, D. S., SOLVOLL, K., BJØRNEBOE, G. E. A. and DREVON, C. A. 1999. Healthy dietary habits in relation to social determinants and lifestyle factors. British Journal of Nutrition, 81(3): 211-220.

JONES, P., COMFORT, D. and HILLIER, D. 2004. A case study on local food and its routes to market in the UK. British Food Journal, 106(4): 328-335.

KISS, K. 2011. How much does the consumption of domestic households burden the environment? [in Hungarian: Mennyire terheli a környezetet a hazai háztartások fogyasztása?]. Mühelytanulmány. Budapesti Corvinus Egyetem, Környezetgazdaságtani és Technológiai Tanszék.

KOTLER, P. and KELLER, K. L. 2012. Marketing Management. 14 th $^{\text {th }}$ Edition. New Jersey: Pearson Education Inc.

LEHOTA, J. 2001. Food Marketing [in Hungarian: Élelmiszergazdasági marketing]. Budapest: Műszaki Press.

LEHOTA, J. 2004. Domestic and international trends in food consumer behavior [in Hungarian: Az élelmiszerfogyasztói magatartás hazai és nemzetközi trendjei]. Élelmiszer, Táplálkozás és Marketing, 1(1-2): 7-14.

LEIP, A., WEISS, F. and WASSENAAR, T. 2010. Evaluation of the Livestock Sector's Contribution to the EU Greenhouse Gas emissions (GGELS). Final Report. European Commission, Joint Research Centre. Available at: http://ec.europa.eu/ agriculture/analysis/external/livestock-gas/index_en.htm [Accessed: 2018, December, 29].

LEITZMANN, C. 2003. Nutrition ecology: the contribution of vegetarian diets. Am. J. Clinical Nutrition, 78(3): 657-659.

LOREK, S. 2005. Sustainable Consumption Governance: A History of Promises and Failures. Journal on Consumer Policy, 28(3): 261-288.

MALHOTRA, N. K. 2005. Marketing Research [in Hungarian: Marketingkutatás]. Budapest: Akadémiai Press.

MCMiCHAEL, A. J., POWLES, J. W., BUTLER, C. D. and UAUY, R. 2007. Food, livestock production, energy, climate change and health. Lancet, 370(9594): 1253-1263.

MELNICK, M. 2011. Tainted Chinese Honey May Be on U.S. Store Shelves. Time Magazine, Aug. 22, 2011. [Online]. Available at: http://healthland.time.com/2011/08/22/tainted-chinese-honey-may-beon-u-s-store-shelves/ [Accessed: 2019, August 04].

MORSE, R. A. and CALDERONE, N. W. 2000. The value of honey bees as pollinators of U.S. crops in 2000. Bee Culture, 128(3): 1-15.

MYERS, N. and KENT, J. 2004. The New Consumers: The Influence Of Affluence On The Environment. Washington D.C. US: Island Press.

NÁDUDVARI, Z. 2004. Sustainable consumption [in Hungarian: Fenntartható fogyasztás]. Environmental Booklets, 1: 29-35. 
NORBERG-HODGE, H. et al. 2002. Bringing the Food Economy Home: Local Alternatives to Global Agribusiness. Bloomfield, CT: Kumarian Press.

PACK, A., FRIEDL, B., LOREK, S., JÄGER, J., OMANN, I. and STOCKER, A. 2005. SUFO:TROP Sustainable Food Consumption: Trends and Opportunities. Interim Report. SERI.

PEPPER, M. J., CARLSON, L., GROVE, S. and KANGUN, N. 2009. International environmental marketing claims - Real changes or simple posturing? International Marketing Review, 14(4): 218-232.

POCOL, C. B., IGNJATIJEVIĆ, S. and CAVICCHIOLI, D. 2017. Production and Trade of Honey in Selected European Countries: Serbia, Romania and Italy. In: DE TOLEDO, V. A. (Ed.). Honey Analysis. IntechOpen, pp. 3-26.

POPP, J., KISS, A., OLÁH, J., MÁTÉ, M., BAI, A. and LAKNER, Z. 2018. Network Analysis for the Improvement of Food Safety in the International Honey Trade. Amfiteatru Economic, 20(47): 84-98.

PREDANOCYOVÁ, K., ŠEDÍK, P., KUBICOVÁ, L. and HORSKÁ, E. 2018. Consumption and offer of organic food on the Slovak market. Acta Universitatis Agriculturae et Silviculturae Mendelianae Brunensis, 66(5): 1315-1323.

PRINCEN, T. 1999. Consumption and environment: some conceptual issues. Ecological Economics, 31(3): 347-363.

RÁCZ, G. 2013. The effects of value transformation and trend of sustainable development on the domestic food consumption [in Hungarian: Az értékek változásának és a fenntartható fejlődés trendjének hatása a hazai élelmiszerfogyasztásra]. PhD. Thesis. Gödöllő: Szent István University. Doctoral School of Management and Business.

RAJAN, T. V., TENNEN, H., LINDQUIST, R. L., COHEN, L. and CLIVE, J. 2002. Effect of Ingestion of Honey on Symptoms of Rhinoconjunctivitis. Annals of Allergy, Asthma and Immunology, 88(2): 198-203.

REISCH, L. A. and ROPKE, I. 2004. The Ecological Economics of Consumption. Current Issues in Ecological Economics series. Edward Elgar.

ROOS, E., PRÄTTÄLÄ, R., LAHELMA, E., KLEEMOLA, P. and PIETINEN, P. 1996. Modern and healthy? Socio-economic differences in the quality of diet. European Journal of Clinical Nutrition, 50(11): 753-760.

ROOS, G., JOHANSSON, L., KASMEL, A., KLUMBIENÄ, J. and PRÄTTAÄLÄ, R. 2001. Disparities in vegetable and fruit consumption: European cases from the north to the south. Public Health Nutrition, 4(1): 35-43.

SAJTOS, L. and MITEV, A. 2007. SPSS Research and Data Analysis Handbook [in Hungarian: SPSS kutatási és adatelemzési kézikönyv]. Budapest: Alinea Press.

SCHNEIDER, A. 2011. Tests Show Most Store Honey Isn't Honey. Food Safety News. [Online]. Available at: https://www.foodsafetynews.com/2011/11/tests-show-most-store-honey-isnt-honey/ [Accessed: 2018, April 11].

SCHÖNHART, M., PENKER, M. and SCHMID, E. 2008. Sustainable local food production and consumption - Challenges for implementation and research. In: $8^{\text {th }}$ European IFSA Symposium. Clermont-Ferrand, 6-10 July.

SMIL, V. 2000. Feeding the World: A Challenge for the Twenty-first Century. Cambridge, MA: MIT Press.

SMITH, A. M. and BAGHURST, K. I. 1992. Public health implications of dietary differences between social status and occupational category groups. Journal of Epidemiology and Community Health, 46(4): 409-416.

SMITH, B. G. 2008. Developing sustainable food supply chains. Philosophical Transactions of the Royal Society B, 363(1492): 849-861.

SUSTAIN. 2009. What is sustainable food. Sustain. [Online]. Available at: www.sustainweb.org/page. php [Accessed: 2009, April 04].

SZAKÁLY, Z. 2011. Nutrition-marketing [in Hungarian: Táplálkozásmarketing]. Budapest: Mezőgazda Press.

SZAKÁLY, Z. and SZABÓ, G. 2009. Analysis of food self-preservation from producer and consumer perspective [in Hungarian: Az élelmiszer-önrendelkezés aspektusainak elemzése termelői és fogyasztó szemszögbőll]. In: LI. Georgikon Days. October 2009, pp. 861-870.

ŠEDÍK, P., HORSKÁ, E., SKOWRON-GRABOWSKA, B. and ILLÉS, B. C. 2018a. Generation marketing in strategic marketing management: Case study of honey market. Polish Journal of Management Studies, 18(1): 330-331.

ŠEDÍK, P., POCOL, C. B. and HORSKÁ, E. 2017. A Comparison of Beekeeping Sectors between Slovakia and Romania. Bulletin of University of Agricultural Sciences and Veterinary Medicine Cluj-Napoca. Horticulture, 74(2): 189.

ŠEDÍK, P., POCOL, C., HORSKÁ, E. and FIORE, M. 2019. Honey: food or medicine? A comparative study between Slovakia and Romania. British Food Journal, 121(6): 1281-1297. 
ŠEDÍK, P., ZAGUlA, G., IVANiŠOVÁ, E., KŇAZOVICKÁ, V., HORSKÁ, E. and KAČÁNIOVÁ, M. 2018b. Nutrition marketing of honey: chemical, microbiological, antioxidant and antimicrobial profile. Potravinarstvo / Slovak Journal of Food Sciences, 12(1): 767-774.

TILMAN, D. 1999. Global environmental impacts of agricultural expansion: The need for sustainable and efficient practices. Proc. Natl. Acad. Sci. U. S. A., 96(11): 5995-6000.

TUKKER, A., HUPPES, G. GUNIEE, J., HEIJUNGS, R., DE KONING, A., VAN OERS, L., SUH, S., GEERKEN, T., VAN HOLDERBEKE, M., JANSEN, B., NIELSEN, P., EDER, P. and DELGADO, L. 2006. Environmental Impact of Products (EIPRO). Technical Report Series. EUR22284EN. Seville: EC Joint Research CentreIPTS.

TUKKER, A. and JANSEN, B. 2006. Environment impacts of products-a detailed review of studies. J. Ind. Ecol., 10(3): 159-182.

VELLINGA, P. and HERB, N. 1999. Industrial Transformation Science Plan. Bonn: IHDP.

VERMEIR, I. and VERBEKE, W. 2004. Sustainable food consumption: Exploring the consumers attitudebehaviour gap. Diploma Thesis. Gent University, Faculty of Economics and Applied Economics.

WeSthoEK, H., ROOD, T., and VAN DEN BERG, M. 2011. The Protein Puzzle. The Hague: PBL Netherlands Environmental Assessment Agency.

WILLIAMS, A. G., AUDSLEY, E. and SANDARS, D. L. 2006. Determining the Environmental Burdens and Resource Use in the Production of Agricultural and Horticultural Commodities. Main Report. Defra Research Project IS0205. Bedford: Cranfield University and Defra.

WINTER, M. 2003. Embeddedness, the New Food Economy and Defensive Localism. Journal of Rural Studies, 19(1): 23-32.

Contact information

Titanilla Oravecz: Oravecz.Titanilla@uni-bge.hu

Laszlo Mucha: mucha.laszlo@phd.uni-szie.hu

Robert Magda: Magda.Robert@gtk.szie.hu

Gedeon Totth: Totth.Gedeon@uni-bge.hu

Csaba Bálint Illés: Illes.B.Csaba@gtk.szie.hu 